\title{
Human testis-expressed (TEX) genes: a review focused on spermatogenesis and male fertility
}

Hela Bellil ${ }^{1}$, Farah Ghieh ${ }^{2,3}$, Emeline Hermel $^{2,3}$, Béatrice Mandon-Pepin ${ }^{2,3}$ and François Vialard ${ }^{1,2,3^{*}}$ (D)

\begin{abstract}
Spermatogenesis is a complex process regulated by a multitude of genes. The identification and characterization of male-germ-cell-specific genes is crucial to understanding the mechanisms through which the cells develop. The term "TEX gene" was coined by Wang et al. (Nat Genet. 2001; 27: 422-6) after they used cDNA suppression subtractive hybridization (SSH) to identify new transcripts that were present only in purified mouse spermatogonia. TEX (Testis expressed) orthologues have been found in other vertebrates (mammals, birds, and reptiles), invertebrates, and yeasts. To date, 69 TEX genes have been described in different species and different tissues. To evaluate the expression of each TEX/tex gene, we compiled data from 7 different RNA-Seq mRNA databases in humans, and 4 in the mouse according to the expression atlas database.

Various studies have highlighted a role for many of these genes in spermatogenesis. Here, we review current knowledge on the TEX genes and their roles in spermatogenesis and fertilization in humans and, comparatively, in other species (notably the mouse). As expected, TEX genes appear to have a major role in reproduction in general and in spermatogenesis in humans but also in all mammals such as the mouse. Most of them are expressed specifically or predominantly in the testis. As most of the TEX genes are highly conserved in mammals, defects in the male (gene mutations in humans and gene-null mice) lead to infertility. In the future, cumulative data on the human TEX genes' physiological functions and pathophysiological dysfunctions should become available and is likely to confirm the essential role of this family in the reproductive process. Thirteen TEX genes are now referenced in the OMIM database, and 3 have been linked to a specific phenotype. TEX11 (on Xq13.1) is currently the gene most frequently reported as being associated with azoospermia.
\end{abstract}

Keywords: Testis-expressed gene, TEX, Male infertility, Spermatogenesis, Mouse model, Genetic defect

\footnotetext{
* Correspondence: francois.vialard@uvsq.fr

'Département de Génétique, CHI de Poissy St Germain en Laye, Poissy,

France

${ }^{2}$ Université Paris-Saclay, UVSQ, INRAE, BREED, F-78350 Jouy-en-Josas, France

Full list of author information is available at the end of the article
}

(c) The Author(s). 2021 Open Access This article is licensed under a Creative Commons Attribution 4.0 International License, which permits use, sharing, adaptation, distribution and reproduction in any medium or format, as long as you give appropriate credit to the original author(s) and the source, provide a link to the Creative Commons licence, and indicate if changes were made. The images or other third party material in this article are included in the article's Creative Commons licence, unless indicated otherwise in a credit line to the material. If material is not included in the article's Creative Commons licence and your intended use is not permitted by statutory regulation or exceeds the permitted use, you will need to obtain permission directly from the copyright holder. To view a copy of this licence, visit http://creativecommons.org/licenses/by/4.0/ The Creative Commons Public Domain Dedication waiver (http://creativecommons.org/publicdomain/zero/1.0/) applies to the data made available in this article, unless otherwise stated in a credit line to the data. 


\section{Résumé}

La spermatogenèse est un processus complexe régulé par une multitude de gènes. L'identification et la caractérisation des gènes spécifiques des cellules germinales mâles sont essentielles pour comprendre les mécanismes par lesquels les cellules se développent. Le terme "gène TEX» a été inventé par Wang et al. (Nat Genet. 2001; 27: 422-6) après avoir utilisé l'hybridation soustractive d'ADNc (SSH) pour identifier de nouveaux transcrits qui n'étaient présents que dans la spermatogonie de souris. Puis, des orthologues TEX ont été trouvés chez d'autres vertébrés (mammifères, oiseaux et reptiles), des invertébrés et des levures. À ce jour, 69 gènes TEX (Testis expressed) ont été décrits dans différentes espèces et différents tissus. Pour évaluer l'expression de chaque gène TEX/tex, nous avons compilé les données de 7 bases de données différentes d'ARNm RNA-Seq chez l'homme, et 4 chez la souris selon la base de données de l'atlas d'expression.

Diverses études ont mis en évidence le rôle de plusieurs de ces gènes dans la spermatogenèse. Ici, nous passons en revue les connaissances actuelles sur les gènes TEX et leurs rôles dans la spermatogenèse et la fécondation chez I'humain et, comparativement, chez d'autres espèces (notamment la souris). Comme prévu, les gènes TEX semblent avoir un rôle majeur dans la reproduction en général et dans la spermatogenèse chez l'homme, mais aussi chez d'autres mammifères comme la souris. La plupart d'entre eux sont exprimés spécifiquement ou principalement dans les testicules. Comme la plupart des gènes TEX sont hautement conservés chez les mammifères, des défauts chez le mâle (mutations géniques chez l'homme et KO murin) conduisent à l'infertilité. À l'avenir, l'accumulation des données sur les fonctions physiologiques et les dysfonctionnements physiopathologiques des gènes TEX humains devraient devenir disponibles et confirmer le rôle essentiel de cette famille dans le processus de reproduction. Treize gènes TEX sont désormais référencés dans la base de données $O M I M$, et 3 ont été liés à un phénotype spécifique. TEX11 (sur Xq13.1) est. actuellement le gène le plus fréquemment rapporté comme étant associé à l'azoospermie.

Mots clés: Testis-expressed gene, TEX, infertilité masculine, spermatogenèse, modèle murin, défaut génétique

\section{Introduction}

Male and/or female infertility (defined as the inability to conceive a child within 1 year of regular unprotected intercourse) affects up to $15 \%$ of couples [1]. Infertility is due to male factors in $40-50 \%$ of couples and can be due to environmental exposure, infections, immune problems or hormone deficiencies [2]. In $15-30 \%$ of all cases, genetics factors are involved [3].

Male germ cell development (spermatogenesis) is a tightly regulated developmental process that occurs through successive mitotic, meiotic and post-meiotic phases (in spermatogonia, spermatocytes and spermatids, respectively) [4]. During spermatogenesis, gene expression is regulated in three ways: intrinsically, interactively and extrinsically. The intrinsic program determines which genes are used and when these genes are expressed. The interactive regulation involves communication between germ cells and somatic cells. Lastly, the extrinsic program influences the interactive process through hormonal regulation [5].

The regulation of spermatogenesis involves the expression of a large number of genes in a precise cell- and stage-specific program [5]. A comprehensive understanding of spermatogenesis requires the identification and functional characterization of the 2300 or so genes that are predominantly expressed in the testes [6]. In the 2000s, the use of cDNA (complementary DNA) library construction techniques and the comparison of gene transcription profiles under different physiological conditions enabled the identified of genes specifically expressed in testis or gonads (named as the testisexpressed (Tex) genes). However, no information on the new gene family's function (notably in the testis) was initially available [7].

Here, we review current knowledge on the TEX genes in humans and other species (notably the mouse) and focus on the genes' roles in spermatogenesis and fertilization. Importantly, some of the TEX genes constitute promising biomarkers of male infertility.

\section{How the first TEX genes were identified and named}

The term "TEX" for testis-expressed was coined by Wang et al. after they used cDNA suppression subtractive hybridization $(\mathrm{SSH})$ to identify new transcripts that were present only in purified mouse spermatogonia [7]. Ten of the 23-novel germ-cell-specific genes, highly or exclusively testis-expressed (Tex11 to 20) had not been annotated previously, and the human TEX orthologs were subsequently described [7]. Most of these genes have since been found to have a function in spermatogenesis, and additional TEX genes have been identified.

Before Wang et al.'s report, the Tex genes had been confused with the t-complex testis-expressed (Tctex) 
genes. The mouse $\mathrm{t}$-complex corresponds to a portion of mouse chromosome 17 that had been identified in mouse t-haplotypes [8]. This t-haplotype contains four non-overlapping, paracentric inversions that span a genetic distance of $20 \mathrm{cM}$ (centiMorgan). This results in a 100-200-fold suppression of recombination, which in turn keeps the haplotypes intact and leads to their divergence from the wild-type chromosomes. There are relatively few Tctex genes: Tctex3, Tctex7, Tctex8, Tctex9, Tctex10, Tctex11, and Tctex12. The genes are expressed predominantly in the germ cells of the testis, and map to various regions of the $t$-complex. Three genes are more abundantly expressed at the pachytene stage; three others are expressed after meiosis, and one (Tctex10) is expressed at all stages of spermatogenesis [8]. Two orthologs have been observed in the human: TCTEX6 (also named TEX6) and PPP1R11 (TCTEX5). To date, 69 TEX or Tex genes have been described in humans or mouse models. However, as described below, these genes do not constitute a homogeneous family; in contrast as the HOX (homeobox) or PAX (paired box) or RHOX (X-linked reproductive homeobox) genes with high sequence identity and very similar functions, the sole common feature of the Tex/TEX genes is their expression (solely or primarily) in the testis. After Wang et al.'s report, new testis-specific genes have been included in the TEX family and numbered sequentially. The TCTEX and TEX gene families are not related as such.

\section{The TEX gene family}

As mentioned above, 69 expressed TEX or Tex genes (61 human genes and 61 mouse genes (Fig. 1)) are listed in the main databases (https://gtexportal.org/ home/, https://www.ensembl.org/index.html, https:// www.omim.org/, etc.). These genes are distributed throughout the genome. To evaluate the expression of each TEX/Tex gene, we compiled data from 7 different RNA-Seq mRNA databases in humans, and 4 in the mouse according to the expression atlas database (https://www.ebi.ac.uk/gxa/home).

The 7 databases for RNA-Seq mRNA results in humans were:

(1) the Genotype-Tissue Expression database (http:// www.genome.ucsc.edu/gtex.html): 53 tissue.

(2) Hallstrom et al.'s database [9]: 95 individuals representing 27 tissues.

(3) the Uhlen laboratory's database (https://www. proteinatlas.org/humanproteome): 122 individuals representing 32 tissues.

(4) the Illumina Body Map [10]: 16 tissues.

(5) the ENCODE project database from Snyder's lab (https://www.encodeproject.org/): 13 tissues.

(6) the mammalian database from Kaessmann's lab [11]: 6 tissues, used to investigate the evolution of gene expression levels in different organs.

(7) the Functional Annotation of the Mammalian Genome (FANTOM) 5 project (https://fantom.gsc. riken.jp/data/): 57 tissues

The 4 databases for RNA-Seq mRNA results in the mouse were:

(1) the mammalian database from Kaessmann's lab [11]: 6 tissues (as in humans).

(2) the FANTOM database 5 projects: (https://fantom. gsc.riken.jp/data/): 35 tissues

(3) the strand-specific RNA-seq of nine C57BL6 mouse tissues: 8 tissues.

(4) Soumillon et al.'s database on brain, liver, and the whole testis [12]: 3 tissues

The data are reported in Table 1 (for humans), Table 2 (for mice), and Table 3 (for other species). For each gene, the highest level of tissue mRNA expression and the mean testis ratio (the ratio between testis expression

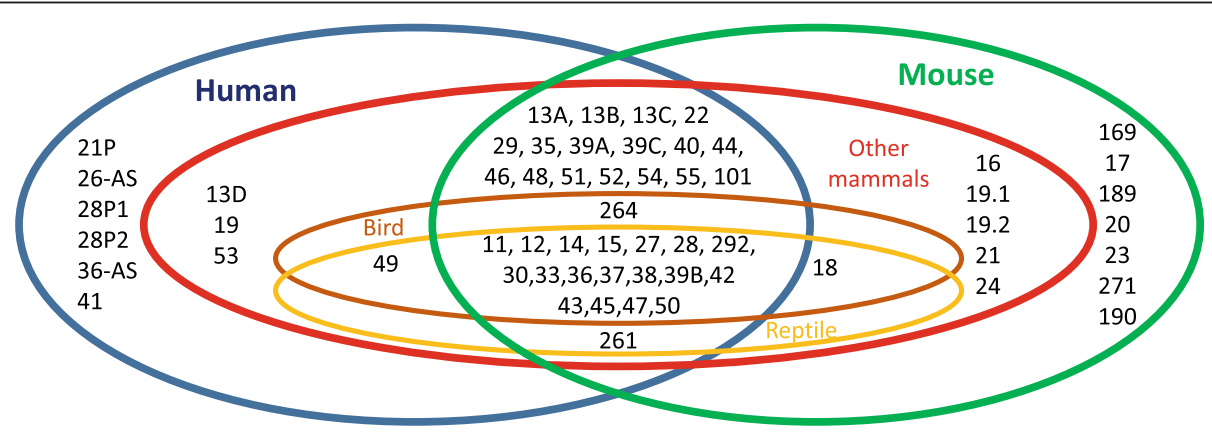

Fig. 1 TEX expression according to species. TEX genes are common to the different species mentioned above, others are specific to each specie. Blue circle included TEX genes expressed in human, green circle included Tex genes expressed in mouse, red circle included tex genes expressed in mouse, red circle included tex genes expressed in other mammals, brown circle included tex genes expressed in birds, yellow circle included tex genes expressed in reptile 
Table 1 Human mRNA TEX gene expression, TEX expression and localization, OMIM reference

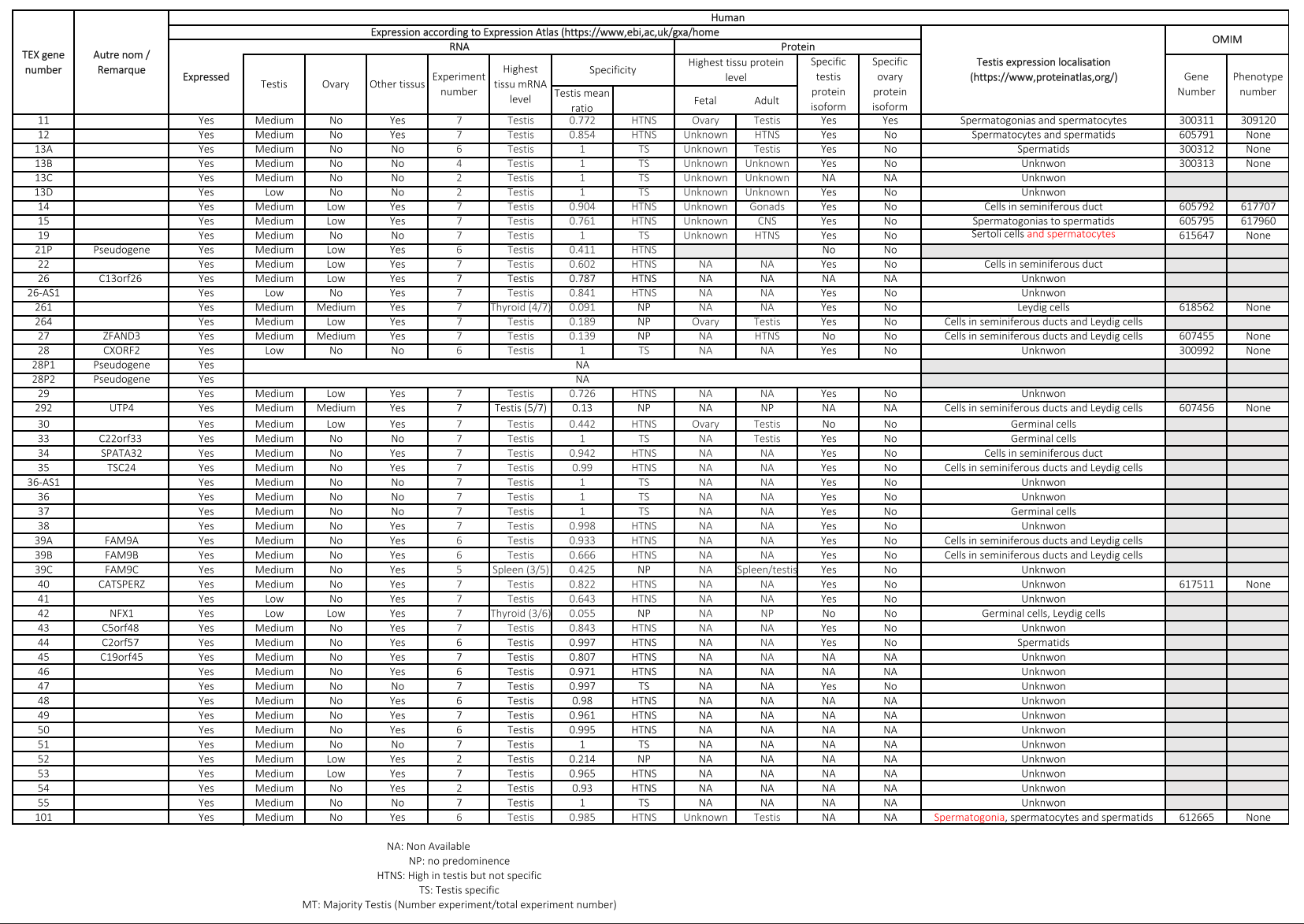

and the total expression level for all other tissues) were reported in humans and mice. Protein expression evaluated according to the Human Protein Atlas (https:// www.proteinatlas.org/) and the Human Proteome Map [13] was only reported for humans. The site of expression in the human testis was reported according to the Human Protein Atlas.

tex orthologues have been found in other vertebrates (mammals (mainly Rattus norvegicus, Macaca mulatta, Equus caballus and Bos taurus), birds (Gallus gallus), and reptiles), invertebrates (Drosophila melanogaster and Caenorhabditis elegans), and yeasts (Saccharomyces cerevisiae) (Table 3). RNA expression in species other than the human was reported according to the Expression Atlas (https://www.ebi.ac.uk/gxa/home).

In the following paragraphs, TEX1 to TEX10 genes are not considered. As mentioned above, TCTEX genes are not considered to be members of the TEX family, even though mutations in some of them (such as TEX8 and CAPZA3) result in male infertility in the mouse (due to sperm with abnormally shaped heads and poor motility). Ultimately, only 62 TEX genes have been defined as such.

\section{Evolutionary conservation of the TEX genes}

Data are summarized in Fig. 1

\section{Conservation of identity between vertebrates and invertebrates}

Fifty-three of the 62 genes reported in Tables 1, 2, 3 do not have identified or reported orthologues in invertebrates. For the 9 other genes (all of which are testisspecific in humans), orthologues have been identified in Drosophila melanogaster, Caenorhabditis elegans and/or Saccharomyces cerevisiae. Five of the 9 genes (TEX13A, $B, C, D$ and TEX28) are also testis-specific in other mammals - indicating a high degree of conservation and a strong probable impact on spermatogenesis. TEX13 is thought to be the ancestral gene. However, a large proportion of the TEX genes appear to be vertebratespecific - confirming the differences in spermatogenesis between vertebrates and invertebrates [14].

\section{Conservation of identity between vertebrates}

Thirty-nine of the 62 genes reported in Tables 1, 2, 3 are expressed in humans, mice, and other mammals. Twenty are also expressed in birds and reptiles, 1 is only 
Table 2 Mouse mRNA Tex gene expression, Nucleotids sequence homology (\%) and KO models

\begin{tabular}{|c|c|c|c|c|c|c|c|}
\hline \multirow{3}{*}{$\begin{array}{l}\text { TEX gene } \\
\text { number }\end{array}$} & \multirow{3}{*}{$\begin{array}{c}\text { Nucleotids } \\
\text { sequence } \\
\text { homology } \\
(\%)\end{array}$} & \multicolumn{4}{|c|}{ Mice Expression according to Expression Atlas } & \multirow{2}{*}{\multicolumn{2}{|c|}{ KO observed }} \\
\hline & & \multirow{2}{*}{ Expressed } & \multirow{2}{*}{$\begin{array}{c}\text { Highest } \\
\text { tissu mRNA }\end{array}$} & \multirow{2}{*}{\multicolumn{2}{|c|}{\begin{tabular}{cc|}
$\begin{array}{c}\text { Experiment } \\
\text { number }\end{array}$ & restis mean \\
\end{tabular}}} & & \\
\hline & & & & & & \multicolumn{2}{|l|}{ Male fertility } \\
\hline 1 & $89.08(\mathrm{n})$ & Yes & Testis (2/4) & 4 & 0.193 & \multicolumn{2}{|r|}{ Phenotype not described } \\
\hline 2 & $87.28(\mathrm{n})$ & Yes & $\begin{array}{l}\text { Testis } \\
\end{array}$ & 4 & 0.0669 & Not described & Eye, behavior neurological phenotype and homeostasis/metabolism phenotypes \\
\hline 6 & $80.76(\mathrm{n})$ & Yes & Testis & 4 & 0.289 & \multicolumn{2}{|r|}{ Phenotype not described } \\
\hline 9 & $81.35(\mathrm{n})$ & Yes & Testis & 4 & 0.582 & \multicolumn{2}{|r|}{ Phenotype not described } \\
\hline $13 \mathrm{C}$ & $55(n)$ & Yes & NA & & & \multicolumn{2}{|r|}{ Not done } \\
\hline 16 & & Yes & Testis & 3 & 1 & \multicolumn{2}{|r|}{ Phenotype not described } \\
\hline 19.2 & & Yes & Testis & 4 & 1 & \multicolumn{2}{|r|}{ Phenotype not described } \\
\hline 21 & & Yes & Testis & 4 & 1 & \multicolumn{2}{|r|}{ Phenotype not described } \\
\hline 24 & & Yes & Testis & 4 & 1 & \multicolumn{2}{|r|}{ Phenotype not described } \\
\hline 26 & 73,26 & Yes & Testis & 4 & 0.956 & \multicolumn{2}{|r|}{ Phenotype not described } \\
\hline 261 & $91.5(n)$ & Yes & NP & 4 & 0.176 & Not described & Skeleton, immune system, growth/size/body, adipose tissue defect \\
\hline 264 & $85.48(n)$ & Yes & $\begin{array}{c}\text { Ryartey } \\
12(1) \mid\end{array}$ & 4 & 0.154 & \multicolumn{2}{|r|}{ Phenotype not described } \\
\hline 27 & $91.71(\mathrm{n})$ & Yes & Testis & 4 & 0.576 & \multicolumn{2}{|r|}{ Phenotype not described } \\
\hline 28 & 72,99 & Yes & Testis & 3 & 1 & \multicolumn{2}{|r|}{ Phenotype not described } \\
\hline 29 & 31.00 & Yes & Testis & 4 & 0.999 & Not described & Behavior/neurological system affected, \\
\hline 30 & 94.07 & Yes & Testis & 4 & 0.772 & \multicolumn{2}{|r|}{ Phenotype not described } \\
\hline 34 & 61,68 & Yes & Testis & 4 & 0.986 & \multicolumn{2}{|r|}{ Phenotype not described } \\
\hline $39 \mathrm{~A}$ & $11(n)$ & Yes & NA & & & \multicolumn{2}{|r|}{ Not done } \\
\hline $39 \mathrm{~B}$ & $35(n)$ & Yes & NA & & & \multicolumn{2}{|r|}{ Not done } \\
\hline $39 \mathrm{C}$ & $8(n)$ & Yes & NA & & & \multicolumn{2}{|r|}{ Not done } \\
\hline 42 & $87.64(\mathrm{n})$ & Yes & CNS & 3 & 0.142 & \multirow{2}{*}{\multicolumn{2}{|c|}{$\begin{array}{l}\text { Phenotype not described } \\
\text { Phenotype not described }\end{array}$}} \\
\hline 43 & 78,61 & Yes & Testis & 4 & 0.998 & \multirow{2}{*}{\multicolumn{2}{|c|}{$\begin{array}{l}\text { Phenotype not described } \\
\text { Phenotype not described }\end{array}$}} \\
\hline 44 & 64,26 & Yes & Testis & 3 & 1 & & \\
\hline 45 & 69,38 & Yes & Testis & 4 & 0.995 & Not described & No abnormal phenotype detected \\
\hline 46 & 73,89 & Yes & Testis & 4 & 1 & & Phenotype not described \\
\hline 47 & 75,63 & Yes & Testis & 4 & 1 & & Phenotype not described \\
\hline 48 & 64,55 & Yes & Testis & 4 & 0.999 & & Phenotype not described \\
\hline 50 & 75,64 & Yes & Testis & 4 & 0.978 & & Phenotype not described \\
\hline 51 & $39(n)$ & Yes & NA & & & & Not done \\
\hline 52 & 75.92 & Yes & Testis & 3 & 0.896 & & Phenotype not described \\
\hline 54 & $55(n)$ & Yes & NA & & & & Not done \\
\hline 55 & 36.00 & Yes & Testis & 4 & 1 & & Phenotype not described \\
\hline 190 & & Yes & Testis & 4 & 0.287 & & Phenotype not described \\
\hline
\end{tabular}

expressed in a bird, 1 is only expressed in a reptile, and 17 are not expressed in birds or reptiles (and so are probably mammal-specific). Thirty-three of the 39 genes are expressed specifically in the testis (in 10 cases) or predominantly in the testis (in 22 cases). For the remaining 6 genes, the highest level of gene expression is not observed in the testis. Four of these 6 genes are not even testis-specific (Table 1 ).

Of the 62 genes reported in Tables 1, 2, 3, 6 are solely expressed in human. Three are pseudogenes (TEX21P, $28 P 1$ and 28P2), 2 considered to code for antisense RNAs (TEX26-AS1 and TEX36-AS1), and the sixth is TEX41. The RNA expression data (when available) suggests that these 6 genes are testis-specific or at least much more strongly expressed in the testis than in other tissues. Seven of the 62 genes reported in Tables 1, 2, 3 are only expressed in mice; 3 of these are testis-specific expression or a very high testis expression level. For the last 10 genes, RNA expression has been identified in other vertebrates (but not in humans or mice) and appears to be generally testis-specific (mean testis ratios: from 0.944 to 1 ).

\section{Conservation of identity between humans and mice}

When comparing humans and mice, the degree of nucleotide identity sequence ranges from $8.00 \%$ (for TEX39C) to $94.07 \%$ (for TEX30). However, when considering only those genes $(n=26)$ with a mean testis RNA ratio below 0.5 in humans and mice, the degree of nucleotide sequence identity ranges from $31.0 \%$ (for TEX29) to $86.45 \%$ (for TEX12). The 8 genes that are testis-specific in humans are also testis-specific in the mouse. Given the high observed degree of identity, studies of TEX gene function in the mouse are likely to be relevant.

\section{Tex gene expression and function in the mouse}

Tex gene was first reported by Wang et al. in 2001 [7]. Ten of the 25 testis expressed genes, 10 (Tex11 to 20) had not been described previously, and 3 (Tex15, 19 and 20). were expressed in the ovary. A human ortholog has been identified in 5 cases (Tex11 to 15). The analysis of testis cDNA libraries has since enabled the discovery of many other similar genes. Of the 52 Tex genes expressed in the mouse, 13 are testis-specific and 37 have a mean testis ratio below 0.5 . For the $8 \mathrm{Tex}$ genes with a mean testis ratio above 0.5 , the testis is the tissue with the highest RNA expression level. The remaining genes have not been characterized. The available data are summarized in Table 4 and detailed in Table 2.

One or more mouse models (mainly knock-out models) have been produced for 47 of the 52 Tex genes. These models have been used to study the Tex genes' function and the resulting level of male fertility. In fact, the male fertility phenotype is not known or has not been reported for 25 genes. For Tex20, 23, 169, 189 and 
Table 3 Others species mRNA tex gene expression and sequence homology

\begin{tabular}{|c|c|c|c|c|c|c|c|}
\hline \multirow{3}{*}{$\begin{array}{l}\text { TEX gene } \\
\text { number }\end{array}$} & \multicolumn{4}{|c|}{ Other vertebrates expressior } & \multicolumn{3}{|c|}{ Other animal models } \\
\hline & \multicolumn{2}{|c|}{ Other mammals } & \multirow{2}{*}{ Bird } & \multirow{2}{*}{ Reptile } & \multicolumn{3}{|c|}{$\begin{array}{l}\text { Sequence homology (\%) (a: amino } \\
\text { acid or } n \text { : nucleotid sequence) }\end{array}$} \\
\hline & Expression & $\begin{array}{l}\text { Highest tissu } \\
\text { mRNA level }\end{array}$ & & & Drosophila & $\begin{array}{c}\text { Caenorhabditis } \\
\text { elegans }\end{array}$ & $\begin{array}{c}\text { Saccharomyces } \\
\text { cerevisae }\end{array}$ \\
\hline 1 & Yes & NP & Yes & Yes & $64.29(\mathrm{n})$ & 33 (a) & Non \\
\hline 2 & Yes & Testis & Yes & Yes & 21 (a) & 26 (a) & $18(n)$ \\
\hline 4 & Yes & NP & Yes & Yes & & & \\
\hline 6 & Yes & Testis & Yes & Yes & $42(n)$ & $37.82(n)$ & $20(n)$ \\
\hline 8 & No & & Yes & Yes & No & No & $35(n)$ \\
\hline 9 & Yes & Testis & Yes & Yes & 20 (a) & No & No \\
\hline 10 & Yes & Testis & Yes & Yes & $26(a)$ & No & $29 \%$ \\
\hline 11 & Yes & Testis & Yes & Yes & No & No & No \\
\hline 12 & Yes & Testis & Yes & Yes & No & No & No \\
\hline $13 \mathrm{~A}$ & Yes & Testis & No & No & 22 (n) & No & $11(n)$ \\
\hline $13 \mathrm{~B}$ & Yes & Testis & No & No & $16(n)$ & No & $9(n)$ \\
\hline $13 \mathrm{C}$ & Yes & Testis & No & No & $20(n)$ & No & $9(n)$ \\
\hline $13 \mathrm{D}$ & Yes & Testis & No & No & $19(n)$ & No & $8(n)$ \\
\hline 14 & Yes & Testis & Yes & Yes & No & No & No \\
\hline 15 & Yes & Testis & Yes & Yes & No & No & No \\
\hline 16 & Yes & Testis & No & No & & & \\
\hline 169 & No & & No & No & & & \\
\hline 17 & No & & No & No & & & \\
\hline 18 & Yes & NA & Yes & No & & & \\
\hline 189 & No & & No & No & & & \\
\hline 19 & Yes & Testis & No & No & No & No & No \\
\hline 19.1 & Yes & Testis & No & No & & & \\
\hline 19.2 & Yes & Testis & No & No & & & \\
\hline 20 & No & & No & No & & & \\
\hline 21 & Yes & Testis & No & No & & & \\
\hline $21 \mathrm{P}$ & No & & & & & & \\
\hline 22 & Yes & Testis & No & No & No & No & No \\
\hline 23 & No & & No & No & & & \\
\hline 24 & Yes & Testis & No & No & & & \\
\hline 26 & Yes & Testis & Yes & Yes & No & No & No \\
\hline 26-AS1 & No & & No & No & No & No & No \\
\hline 261 & Yes & NP & No & Yes & $56.89(n)$ & No & $34(n)$ \\
\hline 264 & Yes & Kydney & Yes & No & No & No & No \\
\hline 27 & Yes & NP & Yes & Yes & $16(n)$ & $25(n)$ & No \\
\hline 271 & No & & No & No & & & \\
\hline 28 & Yes & Testis & Yes & Yes & $13(n)$ & $14(n)$ & No \\
\hline $28 \mathrm{P} 1$ & No & & No & No & & & \\
\hline $28 \mathrm{P} 2$ & No & & No & No & & & \\
\hline 29 & Yes & Testis & No & No & No & No & No \\
\hline 292 & Yes & NP & Yes & Yes & $41.5(n)$ & $17,0(n)$ & $41.14(n)$ \\
\hline 30 & Yes & Testis & Yes & Yes & No & No & No \\
\hline 33 & Yes & Testis & Yes & Yes & No & No & No \\
\hline 34 & Yes & Testis & No & No & No & No & No \\
\hline 35 & Yes & Testis & No & No & No & No & No \\
\hline $36-A S 1$ & No & & & & & & \\
\hline 36 & Yes & Testis & Yes & Yes & No & No & No \\
\hline 37 & Yes & Testis & Yes & Yes & No & No & No \\
\hline 38 & Yes & Testis & Yes & Yes & No & No & No \\
\hline $39 A$ & Yes & NA & No & No & No & No & No \\
\hline $39 B$ & Yes & NA & Yes & Yes & No & No & No \\
\hline $39 \mathrm{C}$ & Yes & NA & No & No & No & No & No \\
\hline 40 & Yes & Testis & No & No & No & No & No \\
\hline 41 & No & & & & & & \\
\hline 42 & Yes & CNS & Yes & Yes & $49.16(n)$ & $47.56(n)$ & $47.09(n)$ \\
\hline 43 & Yes & Testis & Yes & Yes & No & No & No \\
\hline 44 & Yes & Testis & No & No & No & No & No \\
\hline 45 & Yes & Testis & Yes & Yes & No & No & No \\
\hline 46 & Yes & Testis & No & No & No & No & No \\
\hline 47 & Yes & Testis & Yes & Yes & No & No & No \\
\hline 48 & Yes & Testis & No & No & No & No & No \\
\hline 49 & Yes & Testis & Yes & Yes & No & No & No \\
\hline 50 & Yes & Testis & Yes & Yes & No & No & No \\
\hline 51 & Yes & Testis & No & No & No & No & No \\
\hline 52 & Yes & Testis & No & No & No & No & No \\
\hline 53 & Yes & Testis & No & No & No & No & No \\
\hline 54 & Yes & Testis & No & No & No & No & No \\
\hline 55 & Yes & Testis & No & No & No & No & No \\
\hline 101 & Yes & Testis & & & & & \\
\hline 190 & No & & No & No & & & \\
\hline
\end{tabular}


Table 4 Mouse Tex gene expression in the testis

\begin{tabular}{|c|c|c|c|c|c|c|}
\hline \multirow[b]{2}{*}{$\begin{array}{l}\text { Mean testis } \\
\text { ratio }\end{array}$} & \multicolumn{5}{|l|}{ Highest expression in the testis } & \multirow{2}{*}{$\begin{array}{l}\text { Highest } \\
\text { expression in } \\
\text { other tissues }\end{array}$} \\
\hline & 1 & 1 to 0.8 & $\begin{array}{l}0.8 \text { to } \\
0.6\end{array}$ & $\begin{array}{l}0.6 \text { to } \\
0.4\end{array}$ & $\begin{array}{l}\text { below } \\
0.4\end{array}$ & \\
\hline Tex genes & $\begin{array}{l}13 \mathrm{~A}, 13 \mathrm{~B}, 16,17,19.2,21,22,24 \\
28,44,46,47,55\end{array}$ & $\begin{array}{l}11,12,14,15,19.1,26,29,33,34,35,36,37,38 \\
40,43,45,48,50,52,101\end{array}$ & $\begin{array}{l}189 \\
20,30\end{array}$ & 27 & 190 & $\begin{array}{l}169,23,261,264, \\
271,292,42\end{array}$ \\
\hline
\end{tabular}

292, the mouse model is embryo-lethal. For the other genes, transgenic male mice are fertile in the Tex22, 33, 35, 36, 37 and 271 models, subfertile in the Tex 17, 18 and 40 models, and infertile in the Tex11, 12, 14, 15, 19, 19.1, 38 and 101 models. Below, we provide detailed functional information for a small number of these Tex genes.

\section{Tex11}

The Tex11 gene codes for a protein with a tetratricopeptide repeat motif (mediating protein-protein interactions) and a meiosis-specific domain Spo22 [27, 28]. The gene has 175 orthologs, and the human vs. mouse sequence identify is $74 \%$. In the mouse, TEX11 protein is observed in the cytoplasm and nuclei of type B spermatogonia, with the highest level in zygotene spermatocytes and a basal level in late pachytene spermatocytes [29]. It is the first X-encoded meiosis-specific factor to have been identified in the mouse. The abundant expression of TEX11 protein in type B spermatogonia and early spermatocytes suggest that Tex11 has a key role in the early stages of germ cell development. The generation of Tex11-deficient mice has enabled researchers to elucidate the encoded protein's role in spermatogenesis. In 2008, Yang et al. generated a Tex11-null mice by deleting 27 of the gene's 30 exons. Consequently, spermatogenesis was impaired due to chromosomal asynapsis at the pachytene stage and a low level of crossover formation at the anaphase I stage. Tex11-deficient spermatocytes mostly undergo apoptosis at the pachytene stage, while surviving cells display chromosome nondisjunction at the first meiotic division - causes cell death and male infertility [30]. In another study, Adelman et al. generated a Tex11 mutant strain by deleting gene exon 3, resulting in a frameshift and a termination codon. They found that the mutant males exhibited delayed repair of double-strand breaks (DSBs) in spermatocytes. DSB repair and chromosome synapsis are essential for genetic integrity; their dysfunction can cause various diseases, such as infertility [29]. Tex11 is currently considered to be a constituent of the meiotic nodules involved in recombination and that interact with Sycp2 (a component of the synaptonemal complex) [30].

\section{Tex12}

Tex12 is conserved among vertebrates. It encodes a 14.1 $\mathrm{kDa}$ meiosis-specific protein that does not contain any known protein domains. Tex12 is specifically located in the central element structure of the synaptonemal complex and is strongly expressed in spermatocytes and spermatids during meiotic cell division exclusively [31, 32]. The gene codes for two transcripts (Tex12-201 and Tex12-201) and has 116 orthologs. The human and mouse deduced open reading frames code for a 123residue protein with $86 \%$ identity. Tex12-null mice are infertile. Males show a failure of chromosomal synapsis, whereas females show the loss of ovarian follicles. It has further been demonstrated that Tex12 is a member of the synaptonemal complex, which comprises eight proteins: SYCP1-3, SYCE1-3, tex12 and SIX6OS1 [33].

\section{Tex13}

Tex13 is an X-linked gene expressed exclusively in male germ cells. The Tex13 family has 4 members. Wang et al. identified the first two human orthologs (TEX13A and $B$ ) in 2001 [7]. The degree of human vs. mouse nucleotide sequence identity for Tex13 varies from one database to another. Lastly, 4 Tex13 genes have been identified: according to Profile Alignment software (https://www.ibi.vu.nl/programs/pralinewww/), the percentage nucleotide sequence identity is $50 \%$ for Tex $13 \mathrm{~A}$, 54\% for Tex13B, 30\% for Tex13C, and 32\% for Tex $13 D$. According to the UniProt database (www.uniprot.org/), the percentage is $23 \%$ for TEX13A, 31\% for TEX13B, $6 \%$ for TEX13C, and $8 \%$ for TEX13D. The location of TEX13 proteins within germ cells is nuclear. Using a mouse testicular teratoma cell line (considered to possess the characteristics of male germ cells), Kwon et al. [34] demonstrated that TEX13 expression is regulated in a stage-specific manner at the translational level. The protein migrates first to the nuclei of spermatogenic cells and then to the redundant nuclear envelope of the spermatozoon during spermiogenesis. It is found in mature sperm [34]. Remarkably, TEX13 was found to possess transcriptional repressor activity; its overexpression in GC-2 cells altered the expression levels of 130 genes, suggesting that TEX13 might have a role in transcriptional regulation during spermatogenesis [34]. Lastly, Tex13 was the first gene shown to be transcribed in spermatogonia and whose transcripts are then stored in a translationally inactive state until the late meiotic stage. Male mice hemizygous for a Tex13a or Tex13bnull allele exhibit normal fertility. 


\section{Tex14}

Tex14 codes for a testis-specific protein. The open reading frame's predicted 1450 amino acid sequence consists of an ankyrin repeat domain and a protein kinase- $\mathrm{C}$ domain. It shares $64 \%$ amino acid sequence identity with the predicted human TEX14 protein [35]. TEX14 is an essential component of male and female embryonic intercellular bridges. The protein is strongly expressed in the testis and, more specifically, in seminiferous duct cells (Sertoli cells, spermatogonia, spermatocytes, and spermatids) [35]. It is required for both the formation of intercellular bridges during meiosis and kinetochoremicrotubule attachment during mitosis. TEX14 acts by promoting the conversion of midbodies into intercellular bridges [35]. Tex14-null adult male mice are sterile, while females are fertile [36]. tex14-null males lacked intercellular bridges that connect differentiating germ cells, and so spermatogenesis did not progress beyond the first meiotic division. TEX14 is essential for the maintenance of stable intercellular bridges in gametes of both sexes but their loss specifically impairs male meiosis. Although a low number of oocytes are present in Tex14-null neonatal ovaries, females are fertile [36].

\section{Tex15}

Tex15 codes for a serine-rich protein in the mouse and a 3176 amino acid protein in the human (sequence identity: 47\%) [37]. Tex15 gene is expressed in spermatogonia and early spermatocytes. Its expression is downregulated in pachytene spermatocytes and abundant in postmeiotic germ cells [25]. Tex15-null females are fertile, whereas males are sterile with a dramatically reduced testis size, and a complete lack of pachytene spermatocytes and postmeiotic germ cells [37]. During spermatogenesis, Tex15 encodes for a testis-specific protein required for normal chromosome synapsis and meiotic recombination in germ cells. It is also necessary for DNA DSBs (double-strand breaks) repair. TEX15 might be functionally active at different stages in spermatogenesis. It has been postulated that TEX15 functions downstream of DSB repair by SPO11 (a subunit of a DNA topoisomerase VI-like protein complex that is essential for meiotic recombination) but upstream of DSB repair by RAD51 (RecombinaseA-like 51) and DMC1 (DNA meiotic recombinase 1 ) during the meiotic recombination [37]. It was recently reported that during spermatogenesis, TEX15 binds to MILI - a member of the P-element induced wimpy testis in Drosophila (PIWI) family and that is required for germ cell differentiation. TEX15 silences transposable elements that escape the first round of de novo genome methylation in male germ cells [38]. It has been postulated that TEX15 is an essential epigenetic regulator that might operate as a nuclear effector of MILI by silencing transposable elements through DNA methylation. It has also been reported that in fetal gonocytes, TEX15 interacts with MIWI2 (another PIWI family member) and is required for piwi-interacting-RNA-directed de novo DNA methylation of transposons [39].

\section{Tex18}

Tex18 is a small gene identified first in the mouse by Wang et al. It has a single $240 \mathrm{bp}$ exon and is specifically expressed in male germ cells. The encoded protein does not have any identified domains. A human ortholog of Tex18 has not yet been identified [40]. It was later confirmed that Tex18 is expressed in spermatogonia and then in other stages of male germ cell development [40]. Male Tex18-null mice are subfertile because of abnormal sperm morphology and reduced motility - a phenotype known as asthenoteratozoospermia. Spermatid maturation is unsynchronized and partially impaired in the seminiferous tubules, suggesting that Tex18 is predominantly expressed during spermatid differentiation.

\section{Tex19}

Tex19 is a mammal-specific duplicate gene (since renamed Tex19.1 and Tex19.2) found in the mouse and rat. According to the UniProt database, tex19.1 expression in the embryo decreases after murine embryonic stem and germ cell differentiation. At later stages of development, Tex19 expression is limited to the germ line. tex19.1 transcripts have also been detected in mouse pluripotent stem cells. It is thought that tex19.1 encodes a protein expressed solely in germ cells and pluripotent cells. Male Tex19.1-null mice are infertile, with a defect in meiotic chromosome synapsis, the persistence of DNA DSBs during meiosis, and a loss of post-meiotic germ cells. It was further demonstrated that TEX19.1 [41] and its paralog TEX19.2 [42] interact with PIWI proteins in mouse adult testis to repress transposable genetic elements and maintain genomic stability through successive generations. Furthermore, TEX19.1 was shown to promote Spo11-dependent recombination in mouse spermatocytes [42]. Placental expression of Tex19.1 has also been observed [43]. Accordingly, Tex19.1-null mouse embryos exhibit intra-uterine growth retardation and have small placentas. The observation that mobilization of LINE-1 (Long interspersed nuclear element 1) retrotransposons is restricted by TEX19.1 in mouse embryonic stem cells [44] may explain the placental dysfunction and small size. Lastly, it was recently reported that TEX19.1 maintains acetylated SMC3 (Structural Maintenance of Chromosome 3) and sister chromatid cohesion in postnatal oocytes and prevents aneuploidy [45]. 
Tex27 (Zfand3: zinc finger an1 domain-containing protein 3) Tex27 is exclusively expressed in adult mouse testis. It codes for a protein containing a zinc-finger domain in the carboxy terminal region and a transactivation domain in the amino terminal region. TEX27 may be a transcription factor that is preferentially expressed in postmeiotic cells during mouse spermatogenesis [46]. In bird and reptile models, it was reported that the gene codes for two different transcripts: a short form mainly expressed in the testis, and a long form in the ovary. Sequence analysis revealed an extra exon in the genomic structures of the avian and reptilian ZFAND3 genes. TEX27's physiological functions in the testis and ovary are thought to differ in terms of germ cell maturation and regulatory mechanisms [47]).

\section{Tex33}

Tex33 expression is testis-specific; the encoded protein is found in the cytoplasm of round spermatids but much less in elongated spermatids [48]. Given that spermatogenesis is normal in male tex33-null mice, Tex33 might not be essential [49].

\section{Tex36}

Tex36 expression is testis-specific but male Tex36-null mice are fertile with no observable defects in reproductive organs, suggesting that TEX36 is also dispensable to spermatogenesis [50].

\section{Tex37}

Similarly to Tex36, male Tex37 null mice are fertile and have no detectable defects (vs. wild-type mice) in the testis/body weight ratio, epididymal sperm count, and testicular and epididymal histology [51].

\section{Tex40}

Tex40 protein (also referred to as CATSPERZ) is located in the principal piece of the flagellum. It may represent a late evolutionary adaptation that maximizes fertilization inside the female mammalian reproductive tract [52]. Tex40-null mice are fertile and have a normal sperm count and a normal sperm morphology. However, the flagellum is rigid - impairing motility and leading to reduced fertility in vivo and in vitro. The human CATS PERZ and murine Catsperz are both auxiliary subunits of sperm calcium channel pore-forming proteins involved in the activation of spermatozoon motility. It was recently suggested that downregulation of this protein is the cause of the low sperm motility observed in asthenozospermic males [53].

\section{Tex101}

Tex101 is mainly expressed in testis (from spermatogonia to spermatids) but it also transcribed during oogenesis. Mouse TEX101 is a testicular-germ-cell-specific protein predominantly located on the plasma membrane of germ cells during gametogenesis. TEX101 is one of the 29 glycosylphosphatidylinositol-anchored proteins expressed in the mouse testis, where it might regulate ion channels through CATSPERZ (cation channel, sperm-associated, auxiliary subunit zeta). When spermatogenesis in the testis is complete, the TEX101 protein remains on the sperm surface - including the tail portion. TEX101 is then cleaved from the sperm surface and released into the seminal fluid and is no longer detectable in male germ cells. The protein interacts with various molecules during the post-testicular maturation of spermatozoa, including some members of a disintegrin and metalloproteinase (ADAM) family [54]. In humans, TEX101's role and interactome have yet to be determined.

Although Tex101-null mice produce spermatozoa and oocytes with a normal morphology, males are infertile. Sperm physiology and motility are abnormal, which impair sperm migration into the oviduct and hinder the acrosome reaction. TEX101 is therefore essential for male fertility; it has been suggested that TEX101 operates as a cell surface chaperone involved in the maturation of proteins required for sperm migration and sperm-oocyte interaction (such as Adam3) [49-52, 54-57].

\section{Tex261}

Tex261 is highly expressed in adult testis in general and in the Sertoli cells in particular. It is first expressed after 15 days of post-natal life, which coincides with the presence of pachytene cells from the first wave of meiosis during spermatogenesis. TEX261 expression is not restricted to testis (Tables 1 and 2). It is presumably related to (but distinct from) the steroidogenic acute regulatory gene [58]. More recently, TEX261 was reported to modulate the excitotoxic cell death induced by activation of the N-methyl-D-aspartate receptor - a calcium-permeable ionotropic receptor that has a role in many neurologic disorders [59]). Tex261-null mice show defects of the skeleton, immune system, growth/size/ body, and adipose tissue (Table 2).

\section{Tex264}

Although TEX264 expression has been observed in seminiferous duct cells and Leydig cells (according to the Human Protein Atlas), there are no other data on its expression in the testis. In mammalian cells, TEX264 is a major receptor for selective reticulophagy - a process responsible for the specific sequestration of components inside the endoplasmic reticulum alongside the associated ribosomes [60]. 


\section{Tex292}

Tex292 is also referred to as Utp4. At present, the only data on TEX292 expression in testis corresponds to a report of expression in seminiferous duct cells and Leydig cells. Tex292 inactivation is embryonic-lethal [61]. The only available data relates to processes or cell types not associated to spermatogenesis or germ cells [61].

\section{Human TEX gene expression and defects mRNA expression}

Of the 49 TEX genes expressed in humans, 13 are testis-specific and 27 show a high expression level in testis, with a mean testis ratio above 0.4 (between 0.411 and 0.998$)$. Of the 9 remaining TEX genes, 4 are most strongly expressed in the testis for 4,3 are more strongly expressed in thyroid or spleen, and 2 are pseudogenes. Data are summarized in Table 5 and detailed in Table 1.

\section{Protein expression}

Protein expression data remains scarce. For 14 TEX genes, the protein expression pattern is similar to the mRNA expression pattern. A testis-specific protein isoform has been identified for 29 TEX genes, and expression data are missing for 14 other genes. An ovaryspecific protein isoform has only been identified for TEX11. A highly variable testicular location has been reported for 21 TEX genes (Table 1), although germinal cell expression (from spermatogonia to spermatids) has been reported in 19 cases. Eight proteins are referenced in the OMIM database (https://omim.org/), and defects in 3 of the coding genes (TEX11, 14 and 15) have been linked to phenotypes.

\section{TEX genes, dysregulation of spermatogenesis, and a predisposition to infertility}

Thirteen TEX genes are now referenced in the OMIM database, and 3 have been linked to a specific phenotype. Here, we report only the data associated with gene defects (Tables 6 and 7).

\section{TEX11 (OMIM 300311) [15-20, 62, 63]}

TEX11 (on Xq13.1) is currently the most frequently reported gene as being associated with azoospermia [62]. Using an X-chromosome high-resolution microarray, Yatsenko et al. identified the loss of TEX11 exons 9-11 (607del237bp) in two azoospermic patients with homogeneous or mixed meiotic arrest (47). This in-frame genomic deletion predicted a protein lacking 79 amino acids in the highly conserved sporulation domain SPO22. Additional TEX11 missense and splicing variants were found in $2.4 \%$ of the azoospermic patients but not in any of the 384 men with normal sperm concentrations [19]. Forty variants were subsequently identified by sequencing TEX11 exons 2 to 30 and the flanking intronic regions in a large cohort of infertile men with nonobstructive azoospermia $(n=246)$ and in fertile controls $(n=175)$, [20]. Twenty-one of these variants were singletons (i.e. each was observed in one individual only), while the remaining 19 were observed in 2 or more infertile men and/or fertile controls. Eighteen were identified solely in patients with azoospermia. The variants include exonic missense mutations, exonic silent mutations, exonic frameshift mutations, and intronic mutations. The researchers concluded that TEX11 variants were detected with a significantly higher frequency in men with spermatogenic failure than in controls $(7.3 \%$ versus $1.7 \%$, respectively; $p=0.007$ ) [20]. However, the study did not find any differences between pathologic and benign variants. Since then, additional TEX11 missense variants or deletions have been reported $[47,4852$, 53]; suggesting that this $\mathrm{X}$-linked gene has a major role on azoospermia. Recently, low TEX11 expression was reported in a man with Sertoli-cell-only (SCO) syndrome [2]. TEX11 is linked to spermatogenic failure, X-linked, 2 syndrome in the OMIM database (OMIM 309120).

In 2015, Zhang et al. explored the possible association between single nucleotide polymorphisms (SNPs) in TEX11 and idiopathic male infertility [63]. The homozygous rs6525433 polymorphism genotype was significantly associated with general infertility (odds ratio $(\mathrm{OR})=1.517$, 95\% confidence interval (CI):1.070-2.150, $p=0.019)$ and oligozoospermia $(\mathrm{OR}=1.858,95 \% \mathrm{CI}$ : $1.082-3.192, p=0.023)$ - indicating that the rs6525433 polymorphism has a role in male infertility. The nonsynonymous SNP rs6525433 neutralizes the charged amino acid at position 130 of the TEX11 protein (K130A), which might have a negative effect on its structure. No association between the TEX11 rs4844247 SNP and male infertility was observed. However, carriers of both rs6525433 $\mathrm{C}$ and rs4844247 $\mathrm{T}$ had an increased risk of infertility (95\% CI: 1.042-2.542) [63].

Table 5 Human TEX gene expression in the testis

\begin{tabular}{|c|c|c|c|c|c|c|}
\hline \multirow[b]{2}{*}{ Mean testis ratio } & \multicolumn{5}{|c|}{ Highest expression in the testis } & \multirow{2}{*}{$\begin{array}{l}\text { Highest } \\
\text { expression } \\
\text { in other } \\
\text { tissues }\end{array}$} \\
\hline & 1 & 1 to 0.8 & 0.8 to 0.6 & 0.6 to 0.4 & below 0.4 & \\
\hline TEX genes & $\begin{array}{l}\text { 13A, 13B, 13C, 13D, 19, 28, 33, } \\
36-A S 1,36,37,51,55\end{array}$ & $\begin{array}{l}12,14,26-\mathrm{AS} 1,34,35,38,39 \mathrm{~A}, 40,43, \\
44,45,46,47,48,49,50,53,54,101\end{array}$ & $\begin{array}{l}11,15,22,26 \\
29,39 B, 41\end{array}$ & $21 \mathrm{P}, 30,39 \mathrm{C}$ & $264,27,292,52$ & $261,39 C, 42$ \\
\hline
\end{tabular}


Table 6 Variants of TEX genes identified solely in males with azoospermia and/or infertility

\begin{tabular}{|c|c|c|c|c|c|c|}
\hline $\begin{array}{l}\text { TEX } \\
\text { gene }\end{array}$ & Study & Nucleotide change & Protein change & Type of mutation & $\begin{array}{l}\text { Exon/ } \\
\text { intron }\end{array}$ & $\begin{array}{l}\text { Number of males } \\
\text { with the alteration }\end{array}$ \\
\hline \multirow[t]{32}{*}{ TEX11 } & Krausz et al., 2020 [15] & c.84_651del & p.28del189aa & deletion & Exon 4-9 & 1 \\
\hline & \multirow{2}{*}{$\begin{array}{l}\text { Cannarella et al., } 2020 \\
\text { [16] }\end{array}$} & $\mathrm{c.776C} \rightarrow \mathrm{T}$ & p.Thr259lle & missense mutation & Exon 9 & 1 \\
\hline & & $c .2288 \mathrm{~T} \rightarrow \mathrm{C}$ & p.Val763Ala & missense mutation & Exon 26 & 1 \\
\hline & Sha et al., 2018 [17] & c. $2653 \mathrm{G} \rightarrow \mathrm{T}$ & p.W856C & missense mutation & Exon 29 & 2 brothers \\
\hline & $\begin{array}{l}\text { Nakamura et al., } 2017 \\
{[18]}\end{array}$ & $\mathrm{c} .511 \mathrm{~A} \rightarrow \mathrm{G}$ & p.Met171Val & missense mutation & Exon 8 & 1 \\
\hline & \multirow[t]{6}{*}{ Yatsenko et al., 2015 [19] } & $\mathrm{c.450C} \rightarrow \mathrm{T}$ & p.A150A & splicing mutation & Exon 7 & 1 \\
\hline & & $\mathrm{c.} .511 \mathrm{~A} \rightarrow \mathrm{G}$ & p.M171V & missense mutation & Exon 8 & 1 \\
\hline & & c.652del237bp & p.218del79aa & deletion & $\begin{array}{l}\text { Exons 10- } \\
12\end{array}$ & 2 \\
\hline & & c. $792+1 G \rightarrow A$ & p.L264spl d & splicing mutation & Intron 11 & 1 \\
\hline & & c. $1837+1 G \rightarrow C$ & p.R612spl d & splicing mutation & Intron 22 & 1 \\
\hline & & c. $2092 \mathrm{G} \rightarrow \mathrm{A}$ & p.A698T & missense mutation & Exon 25 & 1 \\
\hline & \multirow[t]{21}{*}{ Yang et al., 2015 [20] } & c. $-17 \mathrm{~T} \rightarrow \mathrm{C}$ & / & intronic alteration & Intron 3 & 1 \\
\hline & & c. $-48 \mathrm{G} \rightarrow \mathrm{A}$ & / & intronic alteration & Intron 5 & 1 \\
\hline & & 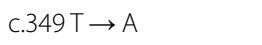 & p.W117R & missense mutation & Exon 6 & 1 \\
\hline & & $\mathrm{c} .405 \mathrm{C} \rightarrow \mathrm{T}$ & / & silent mutation & Exon 6 & 1 \\
\hline & & $c .424 G \rightarrow A$ & p.V142I & missense mutation & Exon 7 & 1 \\
\hline & & c. $466 \mathrm{~A} \rightarrow \mathrm{G}$ & p.M152V & missense mutation & Exon 7 & 1 \\
\hline & & c. $515 \mathrm{~A} \rightarrow \mathrm{G}$ & p.Q172R & missense mutation & Exon 7 & 1 \\
\hline & & $\mathrm{c} .731 \mathrm{C} \rightarrow \mathrm{T}$ & р.T244l & missense mutation & Exon 10 & 1 \\
\hline & & C. $+42 C \rightarrow A$ & / & intronic alteration & Intron 10 & 1 \\
\hline & & c. $-28 \mathrm{~T} \rightarrow \mathrm{C}$ & / & intronic alteration & Intron 12 & 1 \\
\hline & & c. $-64 \mathrm{G} \rightarrow \mathrm{A}$ & / & intronic alteration & Intron 15 & 1 \\
\hline & & c.1258Ins (TT) & $\begin{array}{l}\text { 1258GATG } \rightarrow \text { TTGG } \\
\text { TA }\end{array}$ & frameshift mutation & Exon 16 & 1 \\
\hline & & c. $+16 \mathrm{~A} \rightarrow \mathrm{G}$ & / & intronic alteration & Intron 20 & 1 \\
\hline & & c. $-1 \mathrm{G} \rightarrow \mathrm{A}$ & / & $\begin{array}{l}\text { alteration of splicing acceptor } \\
\text { site }\end{array}$ & Intron 21 & 1 \\
\hline & & c. $-37 \mathrm{~A} \rightarrow \mathrm{G}$ & / & intronic alteration & Intron 22 & 1 \\
\hline & & c. $-44 \mathrm{C} \rightarrow \mathrm{T}$ & / & intronic alteration & Intron 23 & 1 \\
\hline & & c. $+119 \mathrm{G} \rightarrow \mathrm{A}$ & / & intronic alteration & Intron 24 & 1 \\
\hline & & c. $2243 \mathrm{~T} \rightarrow \mathrm{C}$ & p.V748A & missense mutation & Exon 26 & 1 \\
\hline & & $c .2319 \mathrm{~T} \rightarrow \mathrm{C}$ & / & silent mutation & Exon 27 & 1 \\
\hline & & c. $-55 \mathrm{~A} \rightarrow \mathrm{C}$ & / & intronic alteration & Intron 27 & 1 \\
\hline & & c. $-44 \mathrm{~A} \rightarrow \mathrm{G}$ & / & intronic alteration & Intron 28 & 1 \\
\hline \multirow[t]{8}{*}{ TEX14 } & \multirow[t]{3}{*}{ Krausz et al., 2020 [15] } & $\begin{array}{l}\text { c. }\left(554+1 \_555-1\right) \\
\left(3378+1 \_3378-1\right) \text { del }\end{array}$ & p.185del941aa & partial deletion & Exon 6-21 & $\begin{array}{l}1 \text { compound } \\
\text { heterozygote }\end{array}$ \\
\hline & & c.2303_2306del & p.Gln768ArgfsTer31 & frameshift deletion & Exon 14 & \\
\hline & & c. $3454 C>T$ & p.Arg1152Ter & stop gain & Exon 21 & 1 \\
\hline & \multirow[t]{2}{*}{ Araujo et al., 2019 [21] } & c. $727 C>$ G & p.Gln243Glu & missense mutation & Exon 7 & \multirow{2}{*}{$\begin{array}{l}1 \text { compound } \\
\text { heterozygote }\end{array}$} \\
\hline & & c. $4297 G>A$ & p.Glu1433Lys & missense mutation & Exon 31 & \\
\hline & \multirow[t]{3}{*}{ Fakhro et al., 2018 [22] } & C.C254A & p.Arg85Leu & missense mutation & / & 2 brothers \\
\hline & & c. $555-5 \mathrm{~T}>\mathrm{G}$ & / & splice site mutation & / & 1 \\
\hline & & / & p.Ser1255fs & frameshift mutation & / & 1 \\
\hline
\end{tabular}


Table 6 Variants of TEX genes identified solely in males with azoospermia and/or infertility (Continued)

\begin{tabular}{|c|c|c|c|c|c|c|}
\hline $\begin{array}{l}\text { TEX } \\
\text { gene }\end{array}$ & Study & Nucleotide change & Protein change & Type of mutation & $\begin{array}{l}\text { Exon/ } \\
\text { intron }\end{array}$ & $\begin{array}{l}\text { Number of males } \\
\text { with the alteration }\end{array}$ \\
\hline & Gershoni et al., 2017 [23] & c.2668-2678del & early stop codon & frameshift deletion & Exon 16 & 2 brothers \\
\hline \multirow[t]{7}{*}{ TEX15 } & $\begin{array}{l}\text { Cannarella et al., } 2020 \\
\text { [16] }\end{array}$ & C. $7118 \mathrm{G}>\mathrm{A}$ & p.Ser2373Asn & missense mutation & Exon 8 & 1 \\
\hline & \multirow[t]{2}{*}{ Araujo et al., 2019 [21] } & C.7118G > A & p.Ser2373Asn & missense mutation & Exon 8 & \multirow{2}{*}{$\begin{array}{l}1 \text { compound } \\
\text { heterozygote }\end{array}$} \\
\hline & & c. $9223 \mathrm{G}>\mathrm{A}$ & p.Gly3075Arg & missense mutation & Exon 10 & \\
\hline & Wang et al., 2018 [24] & c.6934G > A & p.R2312X & nonsense mutation & Exon 1 & 1 \\
\hline & \multirow{2}{*}{$\begin{array}{l}\text { Colombo et al., } 2017 \\
{[25]}\end{array}$} & $c .2419 A>T$ & p.Lys807* & nonsense mutation & Exon 8 & \multirow{2}{*}{$\begin{array}{l}\text { 2: brothers } \\
\text { (compound } \\
\text { heterozygotes) }\end{array}$} \\
\hline & & c.3040delT & p.Ser1014Leufs*5 & deletion & Exon 8 & \\
\hline & $\begin{array}{l}\text { Okutman et al., } 2015 \\
\text { [26] }\end{array}$ & c. $2130 T>G$ & p.Y710* & nonsense mutation & Exon 1 & 3 brothers \\
\hline
\end{tabular}

\section{TEX12 (OMIM 605791)}

As in mice, human TEX12 is reportedly essential for the synaptonemal complex [33]. Even though low TEX12 expression has been reported in a patient with SCO syndrome [2, 32], further studies are required to confirm the link between TEX12 variants and defective spermatogenesis.

\section{TEX14 (OMIM 605792) [15, 21-23, 64]}

As in mice, human TEX14 is essential for forming stable intercellular bridges in germ cells [36]. To date, few TEX14 genetic variants have been linked to spermatogenesis failure. The first (a 10-bp deletion) variant was identified in 2017 in two infertile brothers with nonobstructive azoospermia from a consanguineous Iraqi Jewish family [23]. The variant leads to a frameshift in the TEX14 coding region and thus results in an early stop codon and a truncated protein. Other deleterious variants have been associated with infertility, maturation arrest, and SCO phenotypes [22, 64]. Taken as a whole, these data suggests that alterations in TEX14 gene has a major impact on the onset of azoospermia. TEX14 is now also listed in the OMIM database as being linked to spermatogenic failure 23 syndrome (OMIM 617707). Furthermore, low TEX14 expression has been reported in a patient with the SCO syndrome [2].

\section{TEX15 (OMIM 605795) [2, 26, 37, 63, 65, 66]}

The first nonsense mutation (leading to a premature stop codon) in the TEX15 locus was identified by exome sequencing in a consanguineous Turkish family [26]. The mutation co-segregated with the infertility phenotype; two brothers with nonobstructive azoospermia and an oligozoospermic sibling were homozygous for the mutation. These males presented a drastically reduced testicular size (by more than 50\%) and maturation arrest at the primary spermatocyte stage [26]. Other nonconsanguineous siblings with nonobstructive azoospermia and a low testicular volume have been found to be compound heterozygotes for deleterious TEX15 variants [25]. To date, few damaging variants have been identified (Table 4). TEX15 has now been linked to spermatogenic failure 25 syndrome in the OMIM database (OMIM 617960). Furthermore, low TEX15 expression has been reported in a man with SCO syndrome [2].

Table 7 Polymorphisms in TEX genes associated with azoospermia and/or infertility, according to the literature

\begin{tabular}{|c|c|c|c|c|c|c|c|}
\hline SNP ID & Study & $\begin{array}{l}\text { TEX } \\
\text { gene }\end{array}$ & $\begin{array}{l}\text { Nucleotide change } \\
\text { (according to transcript } \\
\text { variant 1) }\end{array}$ & $\begin{array}{l}\text { Protein } \\
\text { change }\end{array}$ & $\begin{array}{l}\text { Gnomad (https://gnomad. } \\
\text { broadinstitute.org/) frequency in the } \\
\text { general population }\end{array}$ & $\begin{array}{l}\text { Significantly } \\
\text { associated with } \\
\text { male infertility }\end{array}$ & Population \\
\hline rs6525433 & \multirow{3}{*}{$\begin{array}{l}\text { Zhang } \\
\text { et al., } \\
2015 \text { [60] }\end{array}$} & \multirow[t]{3}{*}{ TEX11 } & c. $389 A>G$ & p.Lys130Arg & 0.125 & Yes & \multirow[t]{3}{*}{ Chinese } \\
\hline rs4844247 & & & c. $1351 \mathrm{G}>\mathrm{A}$ & p.Glu451Lys & 0.103 & No & \\
\hline Association & & & & & & Yes & \\
\hline rs323344 & \multirow{2}{*}{$\begin{array}{l}\text { Aston } \\
\text { et al., } \\
2010 \text { [16] }\end{array}$} & \multirow[t]{4}{*}{ TEX15 } & $c .5158 \mathrm{~T}>\mathrm{G}$ & p.Leu1720Val & 0.148 & No & \multirow[t]{2}{*}{ Caucasian } \\
\hline rs323345 & & & c. $5081 A>G$ & p.Asn1694Ser & 0.168 & No & \\
\hline rs323347 & \multirow{2}{*}{$\begin{array}{l}\text { Ruan } \\
\text { et al., } \\
2012 \text { [22] }\end{array}$} & & c.1459T >C & p.Cys487Arg & 0.255 & Yes & \multirow[t]{3}{*}{ Chinese } \\
\hline rs323346 & & & c. $4252 A>G$ & p.lle1418Val & 0.251 & Yes & \\
\hline & $\begin{array}{l}\text { Zhang } \\
\text { et al., } \\
2010[60]\end{array}$ & & & & & No & \\
\hline
\end{tabular}


Various studies have assessed the association between TEX15 polymorphisms and male infertility. One study did not find an no association [65]. In 2015, Ruan et al. analyzed the distribution of SNPs of the TEX15 gene within a male Chinese Han population. The researchers reported that two genetic variants (rs323346 and rs323347) in TEX15 gene conferred susceptibility to spermatogenic failure [66]. However, this finding was not confirmed by Zhang et al. for rs323346 [63].

\section{TEX101 (OMIM 612665)}

In 2013, TEX101 was first suggested as a biomarker for the differential diagnosis of azoospermia [57]. Schiza et al. used an ELISA assay to (i) evaluate the seminal plasma level of TEX101 and the success of vasectomy, (ii) stratify forms of azoospermia, and (iii) better select patients for sperm retrieval. The same group used differential proteomic profiling to evaluate the impact of the common TEX101 missense variant rs35033974 in infertile men with various etiologies. They reported that 8 cell surface proteins and 9 testis-specific secreted proteins were significantly down-regulated in four patients who were homozygous for rs35033974. The researchers have also found that the seminal plasma level of TEX101 in heterozygous males was five times lower $(p=0.0005)$ that in controls [57]. Schiza et al. concluded that the TEX101 rs35033974 variant could then be taken into account in diagnosis of infertility.

\section{Conclusion}

As expected, TEX genes appear to have a major role in reproduction in general and in spermatogenesis in particular. As the only common feature of TEX genes is their expression in the testis, the genes are involved in many different pathways and functions (Fig. 2) in testis cells, germ cells (from spermatogonia to spermatids), Sertoli cells, and Leydig cells. This is true not only in humans but also in all mammals such as the mouse and the rat. In the future, cumulative data on the human TEX genes' physiological functions and pathophysiological dysfunctions should become available Furthermore, further studies of the functional effects of natural knockouts or knockdowns in humans are necessary for defining the list of essential and nonessential testis-specific genes and proteins and thus advancing the biology of human reproduction.

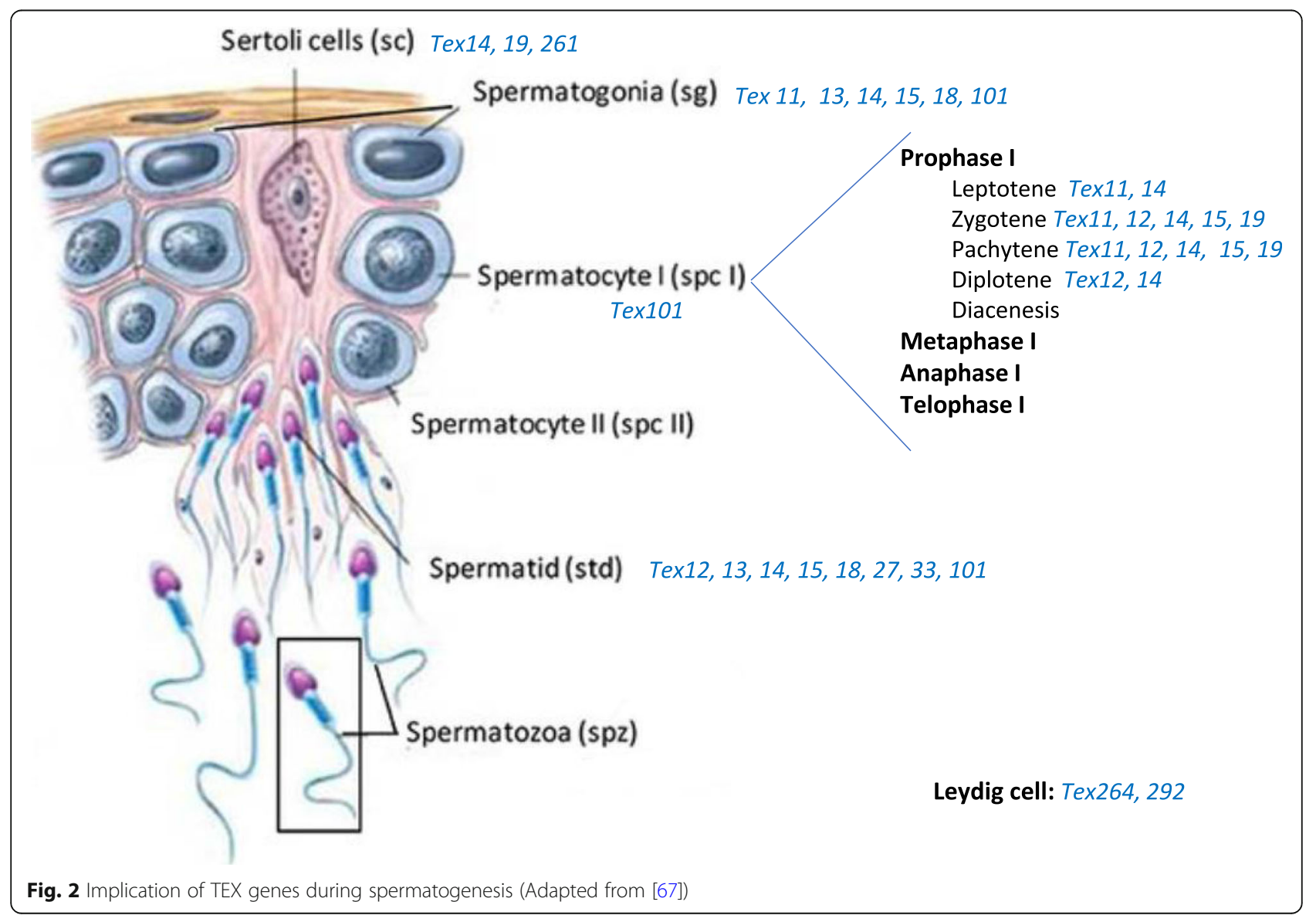




\section{Abbreviations}

CAPZA 3: Capping actin protein of muscle Z-line subunit alpha 3; CATS PERZ: CATion channel, SPERm-associated, auxillary subunit Zeta; CDNA: Complementary DNA; CM: Centimorgan; DMC1: DNA Meiotic reCombinase 1; DSB: Double-strand breaks; ELISA: Enzyme-linked Immunosorbent Assay; FANTOM: Functional annotation of the mammalian genome; HTNS: High in testis but not specific; KO: Knock out; MILI: Miwi-like; MIWI2: (Another PIWI family member); MT: Majority testis; NA: Non available; NP: No predominance; OMIM: Online mendelian inheritance in man; PIWI: Pelement induced wimpy testis; RAD51: RAD51 Recombinase; SCO: Sertoli-cellonly: SIX6OS1: Six6 opposite strand transcript 1; SMC3: Structural maintenance of chromosomes protein 3; SNP: Single nucleotide polymorphisms; SSH: Suppression subtractive hybridization; Sycp2: Synaptonemal complex protein 2; SYCP1-3: Synaptonemal complex protein 1-3; SYCE13: Synaptonemal complex central element protein 1-3; Tctex: T-complex testis-expressed; Tex: Testis expressed; TS: Testis specific; Utp4: U3 small nucleolar RNA-associated protein 4 homolog; Zfand3: Zinc finger AN1 domain-containing protein 3

\section{Acknowledgements}

Jean-Luc VILOTTE for his comments.

\section{Authors' contributions}

$H B, F G$, EH: performed the bibliography screening, wrote the paper; BMP: designed the paper and reviewed the paper, FV: designed the paper and wrote the paper. The author (s) read and approved the final manuscript.

\section{Funding}

None.

\section{Availability of data and materials}

not applicable.

\section{Ethics approval and consent to participate}

not applicable.

\section{Consent for publication}

not applicable.

\section{Competing interests}

None.

\section{Author details}

'Département de Génétique, CHI de Poissy St Germain en Laye, Poissy, France. ${ }^{2}$ Université Paris-Saclay, UVSQ, INRAE, BREED, F-78350 Jouy-en-Josas, France. ${ }^{3}$ Ecole Nationale Vétérinaire d'Alfort, BREED, F-94700 Maisons-Alfort, France.

\section{Received: 2 November 2020 Accepted: 14 February 2021}

\section{Published online: 22 April 2021}

\section{References}

1. Agarwal A, Mulgund A, Hamada A, Chyatte MR. A unique view on male infertility around the globe. Reprod Biol Endocrinol. 2015;13:37.

2. Boroujeni PB, Sabbaghian M, Totonchi M, Sodeifi N, Sarkardeh H, Samadian A, et al. Expression analysis of genes encoding TEX11, TEX12, TEX14 and TEX15 in testis tissues of men with non-obstructive azoospermia. JBRA Assist Reprod. 2018:22:185-92.

3. Shamsi MB, Kumar K, Dada R. Genetic and epigenetic factors: role in male infertility. Indian J Urol. 2011;27:110-20.

4. Jan SZ, Vormer TL, Jongejan A, Röling MD, Silber SJ, de Rooij DG, et al. Unraveling transcriptome dynamics in human spermatogenesis. Development. 2017;144:3659-73.

5. Eddy EM. Male germ cell gene expression. Recent Prog Horm Res. 2002;57: $103-28$.

6. Lu Y, Oura S, Matsumura T, Oji A, Sakurai N, Fujihara Y, et al. CRISPR/Cas9mediated genome editing reveals 30 testis-enriched genes dispensable for male fertility in micet. Biol Reprod. 2019;101:501-11.

7. Wang PJ, McCarrey JR, Yang F, Page DC. An abundance of X-linked genes expressed in spermatogonia. Nat Genet. 2001;27:422-6.
8. Yeom Yl, Abe K, Bennett D, Artzt K. Testis-/embryo-expressed genes are clustered in the mouse H-2K region. Proc Natl Acad Sci U S A. 1992;89:773-7.

9. Fagerberg L, Hallström BM, Oksvold P, et al. Analysis of the human tissuespecific expression by genome-wide integration of transcriptomics and antibody-based proteomics. Mol Cell Proteomics. 2014;13:397-406.

10. Asmann YW, Necela BM, Kalari KR, Hossain A, Baker TR, Carr JM, et al. Detection of redundant fusion transcripts as biomarkers or disease-specific therapeutic targets in breast cancer. Cancer Res. 2012;72:1921-8.

11. Brawand $D$, Soumillon $M$, Necsulea $A$, et al. The evolution of gene expression levels in mammalian organs. Nature. 2011;478:343-8.

12. Soumillon M, Necsulea A, Weier M, Brawand D, Zhang X, Gu H, et al. Cellular source and mechanisms of high transcriptome complexity in the mammalian testis. Cell Rep. 2013;3:2179-90.

13. Kim MS, Pinto SM, Getnet D, Nirujogi RS, Manda SS, Chaerkady R, et al. A draft map of the human proteome. Nature. 2014:509:575-81.

14. Yates AD, Achuthan P, Akanni W, Allen J, Allen J, Alvarez-Jarreta J, et al. Ensembl 2020. Nucleic Acids Res. 2020:48:D682-8.

15. Krausz C, Riera-Escamilla A, Moreno-Mendoza D, Holleman K, Cioppi F, Algaba F, et al. Genetic dissection of spermatogenic arrest through exome analysis: clinical implications for the management of azoospermic men. Genet Med. 2020;22:1956-66.

16. Cannarella R, Condorelli RA, Duca Y, La Vignera S, Calogero AE. New insights into the genetics of spermatogenic failure: a review of the literature. Hum Genet. 2019;138:125-40.

17. Sha Y, Zheng L, Ji Z, Mei L, Ding L, Lin S, Wang $X$, Yang $X$, Li P. A novel TEX11 mutation induces azoospermia: a case report of infertile brothers and literature review. BMC Med Genet. 2018;19:63.

18. Nakamura S, Miyado M, Saito K, Katsumi M, Nakamura A, Kobori Y, et al. Next-generation sequencing for patients with non-obstructive azoospermia: implications for significant roles of monogenic/oligogenic mutations. Andrology. 2017;5:824-31.

19. Yatsenko AN, Georgiadis AP, Röpke A, Berman AJ, Jaffe T, Okszewska M Westernströer B, Sanfilippo J, Kurpisz M, Rajkovic A, Yatsenko SA, Kliesch S, Schlatt S, Tüttelmann F. X-linked TEX11 mutations, meiotic arrest, and azoospermia in infertile men. N Engl J Med. 2015;372:2097-107.

20. Yang $F$, et al. TEX11 is mutated in infertile men with azoospermia and regulates genome-wide recombination rates in mouse. EMBO Mol Med. 2015:7:1198-210.

21. Araujo TF, Friedrich C, Grangeiro CHP, Martelli LR, Grzesiuk JD, Emich J, Wyrwoll MJ, Kliesch S, Simões AL, Tüttelmann F. Sequence analysis of 37 candidate genes for male infertility: challenges in variant assessment and validating genes. Andrology. 2020;8:434-41.

22. Fakhro KA, Elbardisi H, Arafa M, Robay A, Rodriguez-Flores JL, Al-Shakaki A, Syed N, Mezey JG, Abi Khalil C, Malek JA, Al-Ansari A, Al Said S, Crystal RG. Point-of-care whole-exome sequencing of idiopathic male infertility. Genet Med. 2018;20:1365-73.

23. Gershoni M, et al. A familial study of azoospermic men identifies three novel causative mutations in three new human azoospermia genes. Genet Med. 2017:19:998-1006.

24. Wang X, Jin HR, Cui YQ, Chen J, Sha YW, Gao ZL. Case study of a patient with cryptozoospermia associated with a recessive TEX15 nonsense mutation. Asian J Androl. 2018;20:101-2.

25. Colombo R, Pontoglio A, Bini M. Two novel TEX15 mutations in a family with nonobstructive azoospermia. Gynecol Obstet Investig. 2017;82:283-6.

26. Okutman $\mathrm{O}$, et al. Exome sequencing reveals a nonsense mutation in TEX15 causing spermatogenic failure in a Turkish family. Hum Mol Genet. 2015;24: $5581-8$.

27. Blatch $G L$, Lässle $M$. The tetratricopeptide repeat: a structural motif mediating protein-protein interactions. BioEssays. 1999;21:932-9.

28. Chelysheva L, Gendrot G, Vezon D, Doutriaux MP, Mercier R, Grelon M. Zip4/ Spo22 is required for class I CO formation but not for synapsis completion in Arabidopsis thaliana. PLoS Genet. 2007;3:e83.

29. Adelman CA, Petrini JH. ZIP4H (TEX11) deficiency in the mouse impairs meiotic double strand break repair and the regulation of crossing over. PLoS Genet. 2008;4:e1000042 15.

30. Yang F, Gell K, van der Heijden GW, Eckardt S, Leu NA, Page DC, et al. Meiotic failure in male mice lacking an X-linked factor. Genes Dev. 2008;22: 682-91

31. Hamer G, Gell K, Kouznetsova A, Novak I, Benavente R, Hoog C. Characterization of a novel meiosis-specific protein within the central element of the synaptonemal complex. J Cell Sci. 2006;119:4025-32. 
32. Boroujeni PB, Sabbaghian M, Totonchi M, Sodeifi N, Sarkardeh H, Samadian A, et al. Analysis of expression level of TEX12 gene in testis tissues of severe Oligozoospermic and non-obstructive Azoospermic men. Int J Fertil Steril. 2013;7:198.

33. Dunne OM, Davies OR. A molecular model for self-assembly of the synaptonemal complex protein SYCE3. J Biol Chem. 2019;294:9260-75.

34. Kwon JT, Jin S, Choi H, Kim J, Jeong J, Kim J, Cho C. TEX13 is a novel male germ cell-specific nuclear protein potentially involved in transcriptional repression. FEBS Lett. 2016;590:3526-37.

35. Wu MH, Rajkovic A, Burns KH, Yan W, Lin YN, Matzuk MM. Sequence and expression of testis-expressed gene 14 (Tex14): a gene encoding a protein kinase preferentially expressed during spermatogenesis. Gene Expr Patterns. 2013;3:231-6.

36. Greenbaum MP, Iwamori N, Agno JE, Matzuk MM. Mouse TEX14 is required for embryonic germ cell intercellular bridges but not female fertility. Biol Reprod. 2009;80:449-57.

37. Yang F, Eckardt S, Leu NA, McLaughlin KJ, Wang PJ. Mouse TEX15 is essential for DNA double-strand break repair and chromosomal synapsis during male meiosis. J Cell Biol. 2008:180:673-9.

38. Yang F, Lan Y, Pandey RR, Homolka D, Berger SL, Pillai RS, et al. TEX15 associates with MILI and silences transposable elements in male germ cells. Genes Dev. 2020;34:745-50.

39. Schöpp T, Zoch A, Berrens RV, Auchynnikava T, Kabayama Y, Vasiliauskaitè L, et al. TEX15 is an essential executor of MIWI2-directed transposon DNA methylation and silencing. Nat Commun. 2020;11:3739.

40. Jaroszynski L, Dev A, Li M, Meinhardt A, de Rooij DG, Mueller C, et al. Asthenoteratozoospermia in mice lacking testis expressed gene 18 (Tex18). Mol Hum Reprod. 2007;13:155-63.

41. Ollinger R, Childs AJ, Burgess HM, Speed RM, Lundegaard PR, Reynolds N, et al. Deletion of the pluripotency-associated Tex19.1 gene causes activation of endogenous retroviruses and defective spermatogenesis in mice. PLoS Genet. 2008:4:e1000199.

42. Crichton JH, Playfoot CJ, MacLennan M, Read D, Cooke HJ, Adams IR. Tex19. 1 promotes Spo11-dependent meiotic recombination in mouse spermatocytes. PLoS Genet. 2017;13:e1006904.

43. Celebi C, van Montfoort A, Skory V, Kieffer E, Kuntz S, Mark M, Viville S. Tex 19 paralogs exhibit a gonad and placenta-specific expression in the mouse. J Reprod Dev. 2012;58:360-5.

44. MacLennan M, Garcia-Canadas M, Reichmann J, Khazina E, Wagner G, Playfoot CJ, Salvador-Palomeque C, Mann AR, Peressini P, Sanchez L, et al. Mobilization of LINE-1 retrotransposons is restricted by Tex19.1 in mouse embryonic stem cells. Elife. 2017;6:e26152.

45. Reichmann J, Dobie K, Lister LM, Crichton JH, Best D, MacLennan M, Read D, Raymond ES, Hung CC, Boyle S, Shirahige K, Cooke HJ, Herbert M, Adams IR. Tex19.1 inhibits the N-end rule pathway and maintains acetylated SMC3 cohesin and sister chromatid cohesion in oocytes. J Cell Biol. 2020;219: e201702123.

46. de Luis O, López-Fernández LA, del Mazo J. Tex27, a gene containing a zinc-finger domain, is up-regulated during the haploid stages of spermatogenesis. Exp Cell Res. 1999;249:320-6.

47. Otake S, Endo D, Park MK. Molecular characterization of two isoforms of ZFAND3 cDNA from the Japanese quail and the leopard gecko, and different expression patterns between testis and ovary. Gene. 2011;488: 23-34.

48. Kwon JT, Ham S, Jeon S, Kim Y, Oh S, Cho C. Expression of uncharacterized male germ cell-specific genes and discovery of novel sperm-tail proteins in mice. PLoS One. 2017;12:e0182038.

49. Zhu Z, Zhang X, Zeng W, Zhao S, Zhou J, Zhou Z, Liu M. Spermatogenesis is normal in Tex33 knockout mice. PeerJ. 2020;8:e9629.

50. Park S, Shimada K, Fujihara Y, et al. CRISPR/Cas9-mediated genome-edited mice reveal 10 testis-enriched genes are dispensable for male fecundity. Biol Reprod. 2020;103:195-204.

51. Khan M, Jabeen N, Khan T, Hussain HMJ, Ali A, Khan R, Jiang L, Li T, Tao Q, Zhang $X$, Yin H, Yu C, Jiang X, Shi Q. The evolutionarily conserved genes: Tex37, Ccdc73, Prss55 and Nxt2 are dispensable for fertility in mice. Sci Rep. 2018:8:4975

52. Chung JJ, Miki K, Kim D, et al. CatSperל regulates the structural continuity of sperm $\mathrm{Ca} 2+$ signaling domains and is required for normal fertility. Elife. 2017;6:e23082

53. Sinha A, Singh $\mathrm{V}$, Singh S, Yadav S. Proteomic analyses reveal lower expression of TEX40 and ATP6V0A2 proteins related to calcium ion entry and acrosomal acidification in asthenozoospermic males. Life Sci. 2019;218: $81-8$.

54. Schiza C, Korbakis D, Panteleli E, Jarvi K, Drabovich AP, Diamandis EP. Discovery of a human testis-specific protein complex TEX101-DPEP3 and selection of its disrupting antibodies. Mol Cell Proteomics. 2018;17:2480-95.

55. Fujihara Y, Tokuhiro K, Muro Y, Kondoh G, Araki Y, Ikawa M, Okabe M. Expression of TEX101, regulated by ACE, is essential for the production of fertile mouse spermatozoa. Proc Natl Acad Sci. 2013;110:8111-6.

56. Endo S, Yoshitake $H$, Tsukamoto $H$, Matsuura $H$, Kato K, Sakuraba M, et al. TEX101, a glycoprotein essential for sperm fertility, is required for stable expression of Ly6k on testicular germ cells. Sci Rep. 2016;6:23616.

57. Schiza C, Korbakis D, Jarvi K, Diamandis EP, Drabovich AP. Identification of TEX101-associated proteins through proteomic measurement of human spermatozoa homozygous for the missense variant rs35033974. Mol Cell Proteomics. 2019:18:338-51.

58. Lopez-Fernandez, L. A., M. Parraga, and J. del Mazo. 1998. Tex261, a novel gene presumably related but distinct from steroidogenic acute regulatory (StAR) gene, is regulated during the development of germ cells. Biochem. Biophys. Res. Commun. 1998; 242: 565-569.

59. Taniura H, lijima S, Kambe Y, Georgiev D, Yoneda Y. Tex261 modulates the excitotoxic cell death induced by N-methyl-D-aspartate (NMDA) receptor activation. Biochem Biophys Res Commun. 2007:362:1096-100.

60. An H, Ordureau A, Paulo JA, Shoemaker CJ, Denic V, Harper JW. TEX264 Is an Endoplasmic Reticulum-Resident ATG8-Interacting Protein Critical for ER Remodeling during Nutrient Stress. Mol Cell. 2019;74:891-908.e10.

61. Richter A, Mitchell GA, Rasquin A. La cirrhose amérindienne infantile [north American Indian childhood cirrhosis (NAIC)]. Med Sci. 2007;23:1002-7.

62. Ghieh F, Mitchell V, Mandon-Pepin B, Vialard F. Genetic defects in human azoospermia. Basic Clin Androl. 2019;29:4.

63. Zhang $X$, Ding M, Ding $X, L i T$, Chen $H$. Six polymorphisms in genes involved in DNA double-strand break repair and chromosome synapsis: association with male infertility. Syst Biol Reprod Med. 2015;61:187-93.

64. Aston Kl, Krausz C, Laface I, Ruiz-Castané E, Carrell DT. Evaluation of 172 candidate polymorphisms for association with oligozoospermia or azoospermia in a large cohort of men of European descent. Hum Reprod. 2010;25:1383-97.

65. Plaseski T, Noveski P, Popeska Z, Efremov GD, Plaseska-Karanfilska D. Association study of single-nucleotide polymorphisms in FASLG, JMJDIA, LOC203413, TEX15, BRDT, OR2W3, INSR, and TAS2R38 genes with male infertility. J Androl. 2012;33:675-83.

66. Ruan J, He XJ, Du WD, Chen G, Zhou Y, Xu S, Zuo XB, Fang LB, Cao YX, Zhang XJ. Genetic variants in TEX15 gene conferred susceptibility to spermatogenic failure in the Chinese Han population. Reprod Sci. 2012; 19:1190-6.

67. https://www.researchgate.net/figure/lllustration-of-spermatogenesis-Sperma togenesis-occurs-within-the-seminiferous-tubules_fig2_267753964.

\section{Publisher's Note}

Springer Nature remains neutral with regard to jurisdictional claims in published maps and institutional affiliations.

Ready to submit your research? Choose BMC and benefit from:

- fast, convenient online submission

- thorough peer review by experienced researchers in your field

- rapid publication on acceptance

- support for research data, including large and complex data types

- gold Open Access which fosters wider collaboration and increased citations

- maximum visibility for your research: over $100 \mathrm{M}$ website views per year

At $\mathrm{BMC}$, research is always in progress.

Learn more biomedcentral.com/submission 